\title{
The nutritional value of poor proteins fed at high levels
}

\section{The growth of rats*}

\author{
By K. J. CARPENTER AND K. ANANTHARAMAN \\ School of Agriculture, University of Cambridge \\ (Received I August 1967-Accepted 22 November 1967)
}

\begin{abstract}
I. Groundnut flour plus lysine, fed to young rats at a high level as their sole source of protein supported weight gain and nitrogen retention equal to that on what has been considered the 'ideal' egg protein diet. For every 100 metabolizable kcal of the groundnut diet that were consumed, 4I came from the dietary protein and there was a net retention of protein equivalent to $14.5 \mathrm{kcal}$.

2. The predicted retention of protein according to the equations of Miller \& Payne (196r) for this methionine-deficient protein source, given a score of 56 by FAO (I957), would have been equivalent to only 6.r kcal and, whatever the level of such a protein in a diet, the maximum predicted retention would be equivalent to no more than $8.5 \mathrm{kcal}$, or $60 \%$ of the best expected with egg as the protein source.

3. Feeding a lysine-deficient protein source, wheat gluten, at high levels also gave a greater $\mathrm{N}$ retention than had previously been predicted.

4. It is concluded that the Miller \& Payne ( $196 \mathrm{I}, 1963$ ) equations can greatly underestimate the performance to be obtained from feeding poor proteins at high levels. A revised equation (P. R. Payne, private communication) predicts much higher results under these conditions.
\end{abstract}

We began this study from an interest in groundnut flour as a source of protein. It contains only low levels of methionine, lysine and threonine but, despite this, it is being recommended as a supplementary protein for children in developing countries where it is cheap and abundant. Since the grain proteins with which it is generally fed are limiting in the same amino acids, the question arises as to whether good results can be expected from a mixture of proteins having a chemical score of no more than $5^{\circ-60}$ on the FAO (r957) scale, however high a level of protein is used. From the equations of Miller \& Payne (1961, 1963, 1964a) one would conclude that nitrogen retentions could be no more than about $60 \%$ of those obtainable with well-balanced protein whatever the species. However, in a preliminary experiment in our laboratory using chicks (Carpenter \& De Muelenaere, 1965), the results greatly exceeded those expected from the Miller-Payne equations.

This has led us to investigate the source of the discrepancy. We have used both rats and chicks, but the results with chicks are presented in a separate paper (Anantharaman, Carpenter \& Nesheim, 1968). We have also studied both wheat gluten, the example of a material of low chemical score used by Miller \& Payne (1961), and the 'groundnut flour plus lysine' used by Carpenter \& De Muelenaere (1965). Although the first limiting amino acid of groundnut flour is usually calculated to be methionine (Block \& Mitchell, 1946-7; FAO, 1957), more recent feeding tests have indicated that

* Some of these results have been communicated in a preliminary form (Anantharaman \& Carpenter, 1967; Carpenter \& Anantharaman, 1967). 
lysine and threonine may be almost equally as limiting (McOsker, 1962; Black \& Cuthbertson, 1963). By adding supplementary lysine, as in the earlier experiment, we ensured that the same amino acid was not limiting as in gluten. Because of the situation with the rat, of lysine apparently being essential for growth but not for maintenance (or only to a much reduced extent) (Bender, I96r), there is a special reason for expecting a protein limiting in lysine to be used less efficiently at increasing levels, as the proportion used for growth predominates over that used for maintenance.

Finally, we attempted to select protein levels for our diets such that the results would provide a clear-cut test of the Miller \& Payne (I96r, I963) equations regardless of possible disagreement about the chemical score to be assigned to different protein sources. This point requires explanation. Miller \& Payne (196I) analysed their own results, and those of others, from experiments in which young rats had been fed on diets well balanced for minerals and vitamins and containing varying levels of particular protein sources. The concentration of protein in each diet was expressed in terms of $P$, the percentage of metabolizable kcal in the diet supplied by protein. They concluded that, for each protein source, the regression of NPU (op), i.e. net protein retention as a percentage of protein fed, on $P$ was a linear one, with the regression line falling as the protein level rises and intersecting $\mathrm{NPU}_{\mathrm{op}}=$ zero at the same $P$ of 53 . This corresponds to the equation $\mathrm{NPU}_{\mathrm{op}}=b(\mathrm{I}-0.0 \mathrm{I} 9 P)$, where $b$ is a constant, characteristic for the particular protein source.

Now, since $P$ represents the quantity of protein in a diet and $\mathrm{NPU}_{\text {op }}$ the proportion of the protein retained, the product of the two, $P \times \mathrm{NPU}_{\mathrm{op}}$ is a measure of the quantity of protein retained from a given quantity of diet. Specifically this product has been termed NDpCal \%, net protein retained (expressed in kcal) per $100 \mathrm{kcal}$ of dietary $\mathrm{ME}$ received. It follows then from the first regression equation that NDpCal $\%=b\left(P-0.019 P^{2}\right)$, and that for a given value of $b$, the maximal value for NDpCal $\%$ is $\mathrm{I}_{3} \cdot \mathrm{I}_{5} b$, at a $P$ of $26 \cdot 3$. Further, on either side of a $P$ of $26 \cdot 3$ the NDpCal $\%$ falls away at the same rate. For example, it would be the same at a $P$ of $32 \cdot 3$ as at a $P$ of $20^{\circ} 3$, and these were the two levels we chose to aim at in formulating diets containing one or the other of our two low-quality protein sources.

For the formulation of these diets we followed another equation, used by Miller $\&$ Payne (1959), to calculate the metabolizable energy (ME) (kcal/g) of diets as $0.95 \times$ gross energy $(\mathrm{kcal} / \mathrm{g})-0.075 \times \mathrm{N}(\%)$. In some instances, the determined ME values have differed considerably from the calculated ones, and we understand (D. S. Miller \& P. R. Payne, private communication) that these authors have generally used calculated ME values and would prefer them to be used in the application of their prediction equations, even where they are known to differ from actually determined values, because the values of the constants in the prediction equations were derived by means of calculated ME values. A recent modified equation (P. R. Payne, private communication) is also intended for use with calculated values. We have therefore felt obliged to present all our protein values in relation to both calculated and determined ME values. 


\section{EXPERIMENTAL}

\section{Protein sources}

Extracted whole egg, $X$. 624. This was prepared from whole freeze-dried egg (Cressex Laboratories, High Wycombe, Bucks) by solvent-extraction in the laboratory. Successive batches of approximately $500 \mathrm{~g}$ were extracted for $\mathrm{I} 6 \mathrm{~h}$ in a Soxhlet apparatus with 31 . light petroleum (b.p. $40-60^{\circ}$ ) and allowed to dry by spreading out on trays at room temperature.

Groundnut flour, $X .5$ I2. This was the same commercial sample of decorticated, solvent-extracted material (Unilever Ltd, Sharnbrook, Bedfordshire) that had been used in a previous experiment (Carpenter \& De Muelenaere, I965). It contained less than $0.1 \mathrm{ppm}$ aflatoxin as determined with a chloroform extract (Lee, I965) by thinlayer chromatography (Coomes, Crowther, Francis \& Stevens, 1965). For the feeding experiments it was supplemented with $\mathrm{I} \cdot 25 \mathrm{~g}$ L-lysine (as L-lysine hydrochloride; Koch-Light Ltd, Colnbrook, Bucks) per 16 g groundnut N.

Wheat gluten, $X$. 623. This was a commercial sample (Energen Ltd, London, NW 10).

\section{Analytical methods}

Some analyses were carried out on all three materials and the same procedures were also used for the analyses of faecal samples and rat carcasses. Dry matter was determined after heating in a vacuum oven at $70^{\circ}$ for $5 \mathrm{~h}$, and checking for constant weight after a further $2 \mathrm{~h}$ in the oven. $\mathrm{N}$ was determined by the Kjeldahl method using a macro-digestion procedure (Association of Official Agricultural Chemists, I 965 , section 2.044) followed by semi-micro distillation of the ammonia produced into $\mathrm{I} \%(\mathrm{w} / \mathrm{v})$ boric acid containing a mixed indicator for titration with $\mathrm{I} / 70 \mathrm{~N}-\mathrm{HCl}$ (Ma \& Zuazaga, 1942).

Results from two methods of fat analysis are reported. The first was by Soxhlet extraction for $8 \mathrm{~h}$ with light petroleum (b.p. 40-60 ). In the second procedure the test material was first extracted for $8 \mathrm{~h}$ in a Soxhlet with a chloroform-methanol (4:I) mixture; the extract was then dried under vacuum for $2 \mathrm{~h}$ at $70^{\circ}$, repeatedly shaken with cold chloroform and the supernatant liquid filtered, evaporated to dryness and the residue weighed. Chromium was determined by an unpublished modification (C. K. Milner, private communication) of the procedure of Czarnocki, Sibbald \& Evans (I960). Gross energy values were determined in an adiabatic bomb calorimeter (Gallenkamp Ltd, London, EC 2) using tablets of re-crystallized benzoic acid (British Drug Houses Ltd, Poole, Dorset) for calibration.

Fluorodinitrobenzene (FDNB)-reactive lysine was measured by the procedure of Carpenter ( 1960 ) with the values corrected by recovery factors obtained by internal additions of DNP-lysine before the acid-hydrolysis stage. Available methionine was assayed by the Streptococcus zymogenes procedure of Ford (I962) modified only by using $0.4 \%$ crude papain in the digestion mixture (Miller, Carpenter, Morgan \& Boyne, r965). 


\section{Diets}

Diet $A$ (protein-free). This diet was made up of arachis oil 5, ground oat husk 5, a mineral pre-mix (Fox \& Briggs, I960) 6, a vitamin pre-mix (Chapman, Castillo \& Campbell, I959) I, choline chloride 0.3 , chromic oxide 0.3 , an antibiotic supplement (TM-5, containing $\mathbf{2 \cdot 2} \%$ oxytetracycline; Pfizer Ltd, Folkestone, Kent) 0.07 , and maize starch $a d$ 100. The starch used contained $12 \cdot 2 \%$ moisture.

Diets $B-G$ (with ' $F$ ' omitted from the series). These were all modifications of diet A prepared by including one of the protein concentrates at the expense of starch to give the composition shown in Table 2. Diets $\mathrm{B}$ and $\mathrm{D}$ were intended to have a $P$ value of approximately 20 by the Miller \& Payne ( $196 \mathrm{I}$ ) formula, G a value of 26 and $\mathrm{C}$ and E a value of 32 .

Diet $H$ (mixed protein). This diet was designed to be generally similar to mixtures that have supported very rapid and efficient growth in young chicks (Carew, Hopkins $\&$ Nesheim, 1964) and differed from diet $A$ in having extracted toasted soya-bean meal $I_{7} \cdot 5$, crude casein $I_{3}$, herring meal 6 , gelatin 3 , dried brewer's yeast 3 and dried whey 2 , all included at the expense of starch.

A single, large batch of each diet sufficient for this and other experiments was prepared; the portions not needed immediately were stored in sealed tins at $-20^{\circ}$. Analytical information about the diets is set out in Table 2.

\section{Digestibility determinations}

Two experiments were carried out. In the first, six litters of Wistar rats each containing three males and three females were purchased (Animal Suppliers (London) Ltd, Welwyn) at 2I-23 days of age and approximately $40 \mathrm{~g}$ body-weight. At first each litter was kept together in one cage with a raised wire floor. Our animal room was maintained at $27-29^{\circ}$; humidity was not controlled but was usually about $35 \%$. The diet during this period was made up from purified ingredients and included $\mathrm{I} \cdot 6 \% \mathrm{~N}$ from crude casein and $0.3 \%$ DL-methionine. After 7 days the rats were allocated to their dietary treatments. Two litters were first taken and six pairs made up, each containing a male from one litter and a female from the other-where the heaviest male was used from the one litter, the lightest female was taken from the other, and so on. The six pairs were then allocated at random to five experimental treatments (the last pair being discarded) and each pair was placed in a metabolism cage. The procedure was repeated twice more with the remaining four litters.

The five treatments consisted of feeding one of diets $\mathrm{A}, \mathrm{B}, \mathrm{C}, \mathrm{D}$, or E ad lib. as a dry powder for Io days. Faeces were collected twice daily from each group for the last 7 days of the period, and any adhering food particles or hairs were removed. The material was stored at $-10^{\circ}$ until the end of the experiment and then dried in a vacuum oven at $40^{\circ}$ and checked again for any contamination with food particles, before being milled. Duplicate determinations for moisture, chromium, $\mathrm{N}$ and gross energy were then carried out on the faecal samples, by the procedures that had been applied to the diets.

The experiment was then repeated with diets $A, G$ and $H$. Inspection of the final 
results indicated that variability was similar in the results from the two trials, and they were therefore taken together for a single analysis of variance to obtain a pooled estimate of the standard error of treatment means, with 9 degrees of freedom for each value.

The correction from 'apparent' to 'true' digestibility of $\mathrm{N}$ was made up by the common assumption that the quantity of metabolic (i.e. non-dietary) $\mathrm{N}$ in the faeces was proportional to the weight of food eaten. Values obtained from diet A in Expts I and 2 respectively were $0.25 \mathrm{I}$ and $0.259 \mathrm{~g} \mathrm{~N}$ excreted per $100 \mathrm{~g}$ diet eaten; these values were not significantly different. With the further assumption that the small quantity of $\mathrm{N}$ in diet $\mathrm{A}$ was all absorbed, a common value of $0.255 \mathrm{~g}$ endogenous faecal $\mathrm{N}$ per I00 $\mathrm{g}$ diet was taken for the correction from 'apparent' to 'true' digestibility values in each experiment.

The metabolizable energy (ME) values, in $\mathrm{kcal} / \mathrm{g}$, were corrected to $\mathrm{N}$ equilibrium by subtracting from the determined digestible energy a value for urinary energy at $\mathrm{N}$ equilibrium. The latter was estimated (following Forbes, Black, Thacker \& Swift, 1940) as $7.5 \mathrm{kcal} / \mathrm{g}$ urinary $\mathrm{N}$. The urinary $\mathrm{N}$, at equilibrium, was calculated as ' $\mathrm{N}$ fed' minus ' $\mathrm{N}$ excreted in the faeces', all expressed per $100 \mathrm{~g}$ food eaten. The whole urinary correction is a small one, and reducing the factor to $6.5 \mathrm{kcal}$ or raising it to $8.5 \mathrm{kcal} / \mathrm{g}$ urinary $\mathrm{N}$ would change the final metabolizable energy value of the diet by less than $0.05 \mathrm{kcal} / \mathrm{g}$, i.e. by less than $2 \%$. The use of a correction is considered in the following paper (Anantharaman et al. 1968).

A second series of 'calculated ME values' has been worked out from the formula (Miller \& Payne, 1959), which assumes a constant $95 \%$ digestibility of the diet ingredients. From these, calculated values for $P(\%$ of total metabolizable energy which came from protein) were obtained as

$$
\frac{\mathrm{N}(\%) \times 25}{\mathrm{ME}(\mathrm{kcal} / \mathrm{g})} \text { (Miller \& Payne, I96r). }
$$

For our own directly determined results, $P$ has been taken as

$$
\frac{\mathrm{N}(\%) \times 26 \cdot 6}{\mathrm{ME}(\mathrm{kcal} / \mathrm{g})} \times \frac{\text { determined digestibility of } \mathrm{N}(\%)}{100},
$$

so that the two values coincide when the determined digestibility of the protein is also $95 \%$.

\section{The main feeding experiment}

Fourteen litters of rats, each containing four males and four females were purchased and treated up to the time of randomization as in the previous experiments. After 7 days, eleven litters were selected and a further group of eight was made up from the four males of one litter and the females of another, to substitute for a twelfth litter; the remainder were discarded.

For allocation of the animals to treatments, two of the selected litters were taken at random, and pairs were made up with the heaviest male of one litter being placed with the lightest female of the other, the next heaviest with the next lightest and so on. The eight pairs formed the first stratum of the experiment and the procedure was 
repeated to give altogether six strata. The eight pairs from each stratum were then allocated at random to eight treatments, and the pair allocated to treatment $\mathrm{K}$ was killed immediately and the carcasses were stored at $-20^{\circ}$ for subsequent analysis. The remaining pairs were caged together in the forty-eight cage unit already described (Carpenter, March, Milner \& Campbell, I 963) and received the experimental diet for their treatment $a d l i b$. as a dry powder. Spilt food was collected, air-dried and weighed. Our allocation and grouping procedure differed from that described by Miller (1963).

\section{Carcass analysis}

After Io days on the experimental treatments food was withheld from all the rats and $2 \mathrm{~h}$ later they were killed with ether vapour: each rat was placed in an unsealed polythene bag, allowed to cool for $\mathrm{I}-2 \mathrm{~h}$ and then stored at $-20^{\circ}$. For the subsequent work the rats of strata I and 2 were pooled, as were those of strata 3 and 4 , and of 5 and 6 . On each of the next 3 days the rats from one pair of strata were further processed. The four rats from each treatment (i.e. the two cage pairs from strata $I$ and 2 respectively on the Ist day) were weighed to give the 'final dead weights' recorded in Table 4, and then chopped into two or three pieces where necessary and passed, while still frozen, through a $\frac{1}{2}$ h.p. electric meat mincer (model $\mathrm{AB}_{\mathrm{I}}$; Crypto Ltd, London). After the material had been passed through the machine the cutting plate was removed and any skin or material caught behind it was cut up with scissors. All the material was then passed through the mincer again until it was reduced to a smooth paste. Occasional small pieces of solid $\mathrm{CO}_{2}$ were added to prevent the temperature rising to the extent that the fat in the mince melted. A large sample of each mix was then taken and held at $-10^{\circ}$ until it was analysed in duplicate for $\mathrm{N}$ content, with at least to $\mathrm{g}$ material per digest. The intestinal contents were included with the tissues, following the practice of Miller \& Bender (1955).

\section{Calculations of net $N$ retention}

In the Miller \& Bender (1955) procedure, the net $\mathrm{N}$ retention of a treatment group was calculated by subtracting the final $\mathrm{N}$ content of the group that had received the protein-free diet during the test from that of the treatment group itself. As pointed out by Dreyer (1964), this calculation is not really valid since it assumes that the daily endogenous and metabolic losses of the treatment group are also those of the "proteinfree' group even though the former will almost certainly be eating more and become significantly larger over the experimental period. However, we have found that correcting for this difference in size has very little effect on the results in our experiment and it has not been done for the calculations set out in Table 4 .

We have, however, made another correction to allow for differences in initial $\mathrm{N}$ content of the test groups and of the 'protein-free' group. This has no systematic effect on the final values but may reduce the standard errors significantly. Our use of litter-mates and balanced sexes, and the randomization of pairs to treatments tend to result in bigger initial differences than can be obtained by the procedure described by Miller ( 1963 ), where sex and litter are ignored and groups of four rats are balanced to almost equal initial weight. We obtained a value of $2 \cdot 95 \%$ for the $\mathrm{N}$ content of the 
rats killed at the time of randomization (i.e. treatment $\mathrm{K}$ ) and have assumed that the $\mathrm{N}$ contents of different groups of rats at randomization differed by 0.0295 times their difference in live weight. Using this figure for calculating the initial $\mathrm{N}$ content of the remaining groups, the net $\mathrm{N}$ retention, i.e. ' $\mathrm{N}$ gain' of the 'test group' plus the 'N loss of the protein-free group' can be expressed as : 'final $\mathrm{N}$ content of test group' 'final $N$ content of the protein-free group' - 0.0295 (initial live weight of test group initial live weight of protein-free group). We are assuming that the small amount of $\mathrm{N}$ in the protein-free diet is not in the form of useful protein. If we had followed the opposite convention of Miller \& Bender (1955) that it was completely retained, our NPU values would be increased by $0.1-0.3$ units, as may be calculated from Table 2 .

In converting net $\mathrm{N}$ retention into $\mathrm{kcal}$ for the calculation of NDpCal $\%$, Miller 8 Payne (1963) have used a value of $4.0 \mathrm{kcal} / \mathrm{I} 6 \mathrm{~g} \mathrm{~N}$; since the definition of NDpCal comes from these authors, it seems only correct to follow their convention in this respect.

Table I. Characteristics of the protein concentrates used

\begin{tabular}{|c|c|c|c|}
\hline & $\begin{array}{c}\text { Extracted } \\
\text { whole egg } \\
\text { X. } 624\end{array}$ & $\begin{array}{l}\text { Groundnut flour } \\
\quad \mathrm{X} .512\end{array}$ & $\begin{array}{l}\text { Wheat gluten } \\
\text { X. } 623\end{array}$ \\
\hline Dry matter $(\%)$ & $94: 3$ & $92 \cdot 5$ & $90 \cdot 5$ \\
\hline Ether extract $(\%)$ & $2: 7$ & 0.9 & I.I \\
\hline Chloroform extract $(\%)^{*}$ & $14: 4$ & $2 \cdot 5$ & 0.9 \\
\hline $\mathrm{N} \times 6.25(\%)$ & 74.0 & 47.5 & $69 \cdot 8$ \\
\hline FDNB-available lysine $(\mathrm{g} / \mathrm{r} 6 \mathrm{~g} \mathrm{~N}) \dagger$ & $5 \cdot 7$ & 3.0 & $x \cdot 75$ \\
\hline $\begin{array}{l}\text { Streptococcus zymogenes-available } \\
\text { methionine }(\mathrm{g} / \mathrm{r} 6 \mathrm{~g} \mathrm{~N}) \dagger\end{array}$ & $3 \cdot 26$ & $x \cdot 21$ & 2.05 \\
\hline Gross energy (kcal/g) & $5 \cdot 47$ & $4 \cdot 18$ & 4.93 \\
\hline
\end{tabular}

* Test materials first extracted with $\mathrm{CHCl}_{3}-\mathrm{MeOH}(4: 1)$, the extract evaporated and shaken with $\mathrm{CHCl}_{3}$.

$\dagger$ Lysine measured by reaction with fluorodinitrobenzene (Carpenter, 1960), methionine by assay of papain digests with a proteolytic micro-organism (Ford, r 962).

\section{RESULTS}

\section{Composition and digestibility}

The results of the determinations carried out on the three protein sources are given in Table $\mathrm{r}$. There was no evidence of abnormality about any sample. The groundnut flour was very deficient in methionine, and the wheat gluten in lysine, as expected.

The digestion experiments were completed without a hitch, and the determined values had low standard errors. The true digestibility values for $\mathrm{N}$ were close to those expected, i.e. approximately $95 \%$ for animal proteins and a separated vegetable protein such as wheat gluten and approximately $90 \%$ for groundnut meal, i.e. a vegetable material containing structural carbohydrates. Only the 'mixed protein' diet $\mathrm{H}$, with a high soya-bean content, was expected to be significantly lower.

Bigger differences were seen in the digestibility of the gross energy in the different diets (Table 2). However, it had been expected that the determined values for the groundnut flour diets would be considerably lower than those calculated by the standard formula (cf. Carpenter $\&$ De Muelenaere, I965, table 3 ). The greater bulk. 


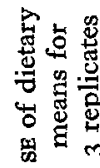

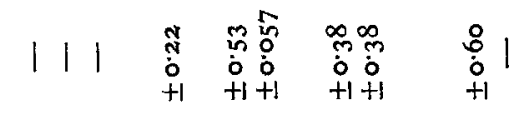

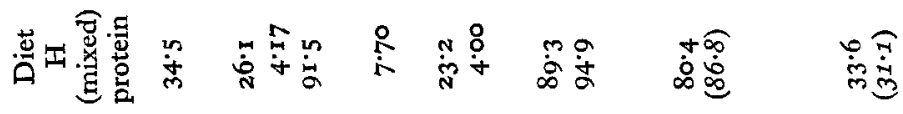

हैं

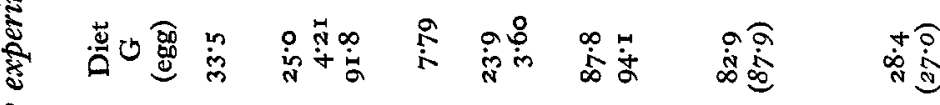

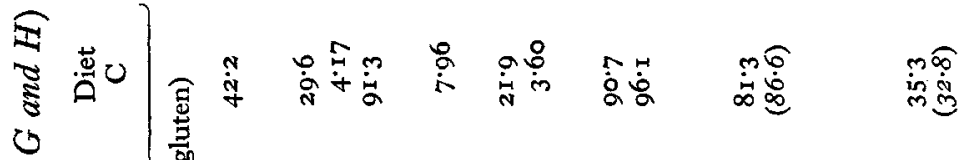

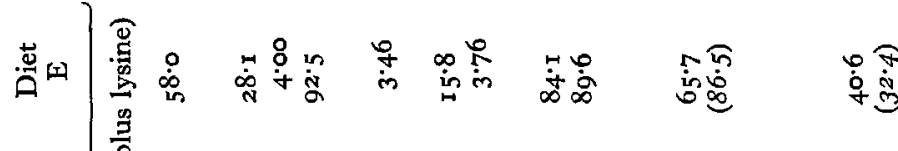

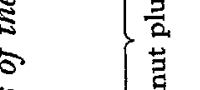

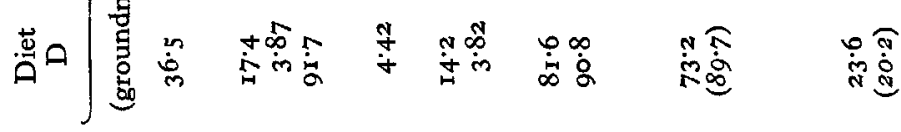

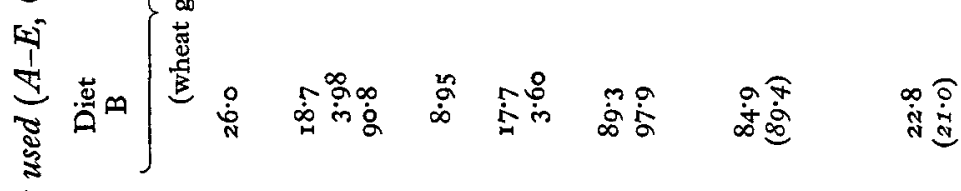

$\frac{\pi}{4}$

कับ

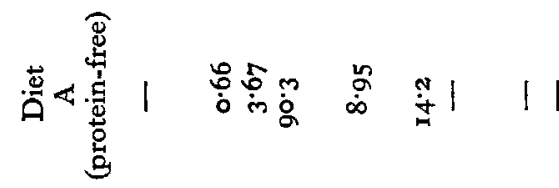

造

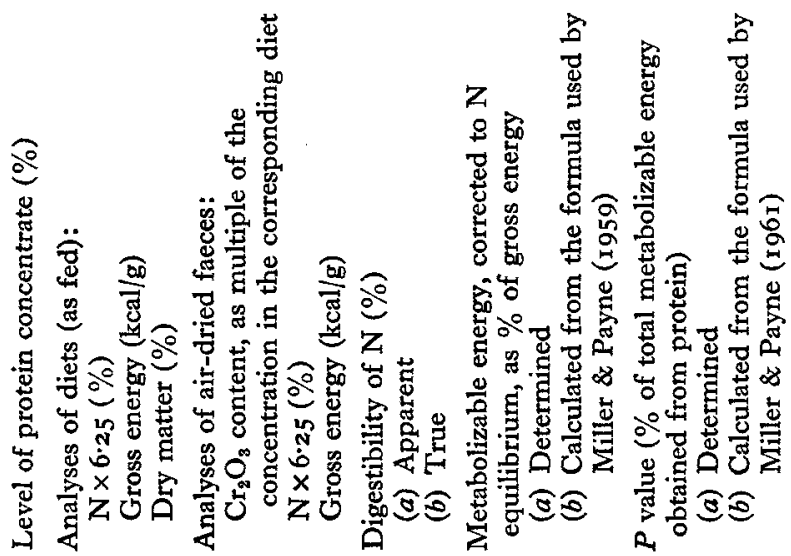


of faeces from rats on these diets, particularly diet $\mathrm{E}$ that contained $58 \%$ groundnut flour, was clearly seen. The faeces were collected as quantitatively as possible although, in separating any spilt food from them, any doubtful fragments were discarded, since complete recovery was not essential when the chromic oxide indicator was used. Calculation of the metabolizable energy of diet $\mathrm{E}$, from the weights of food eaten and of faeces collected, gave a value only $2 \%$ greater than that obtained on the basis of the ratios of $\mathrm{N}$ to chromic oxide in food and faeces. In the literature there are no values with rats for comparison, but the low values obtained here have been confirmed with chicks (Anantharaman et al. 1968).

Because of the difference in the metabolizable energy of the diets, the $P$ values (i.e. \% of metabolizable calories from protein) for the groundnut flour diets also differed according to whether they were based on determined or 'calculated' values, being considerably higher on the determined values.

\section{Table 3. Repeat analyses of diet $E$}

\begin{tabular}{|c|c|c|c|c|c|c|c|}
\hline \multirow[b]{2}{*}{ Laboratory } & \multirow[b]{2}{*}{$\begin{array}{c}\text { Date of } \\
\text { sampling }\end{array}$} & \multirow[b]{2}{*}{$\begin{array}{c}\text { Moisture } \\
(\%)\end{array}$} & \multirow[b]{2}{*}{$\begin{array}{l}N(\%) \\
\text { As fed }\end{array}$} & \multicolumn{2}{|c|}{ Gross energy ( $\mathrm{kcal} / \mathrm{g})$} & \multirow[b]{2}{*}{$\begin{array}{c}\text { Calorimeter } \\
\text { used }\end{array}$} & \multirow[b]{2}{*}{$\begin{array}{c}\text { Calculated } \\
P \text { value }\end{array}$} \\
\hline & & & & As fed & DM basis & & \\
\hline Cambridge & Mar. 1966 & $7 \cdot 5$ & $4 \cdot 49$ & $4^{\circ} 00$ & $4 \cdot 33$ & Adiabatic & $32 \cdot 4$ \\
\hline Cambridge & Dec. 1966 & $9 \circ$ & $4 \cdot 42$ & 4.05 & $4 \cdot 44$ & Adiabatic & $31 \cdot 4$ \\
\hline & Dec. 1966 & $9 \cdot 4$ & $4 \cdot 47$ & $4 \cdot 07$ & $4 \cdot 49$ & Adiabatic & $3 \mathrm{I} \cdot 7$ \\
\hline 'C' & Dec. 1966 & - & - & - & 4.59 & Ballistic & - \\
\hline
\end{tabular}

Some further check analyses were carried out on $\operatorname{diet} \mathrm{E}$ when the experiments had been completed and the results studied. A further sample was taken from the bulk of the diet after it had been in cold store for 9 months and distributed between three laboratories (our own and two others). The results are summarized in Table 3. The variability appeared to be within the limits to be expected from the combination of differences arising from sampling a mixture and from the limitations of analytical procedures.

\section{Nitrogen retention experiment}

The experiment was completed without loss or mishap and the results are summarized in Table 4. It is seen that the rats receiving diet $\mathrm{E}$ (high in groundnut and lysine) had a weight gain, and also a net $\mathrm{N}$ gain, that did not differ significantly from those obtained with either the egg diet $\mathrm{G}$ or the 'mixed protein' diet $\mathrm{H}$. Although the rats receiving diet $\mathrm{E}$ ate a greater weight of food than those receiving $\operatorname{diet} \mathrm{G}$ or $\mathrm{H}$, calculation shows that their intake of metabolizable energy was similar to that of rats receiving $\operatorname{diet} \mathrm{G}$ and less than that of the rats receiving diet $\mathrm{H}$.

Weight gain and $\mathrm{N}$ retention were less with wheat gluten than with the corresponding 'groundnut' diets but for each material performance was superior, by all criteria, at the higher of the two protein levels chosen. Thus, although the proportion of the protein that was retained (i.e. $\mathrm{NPU}_{\mathrm{op}}$ ) was slightly lower, the difference was not sufficient to outweigh the effect of increasing the quantity given. D. S. Miller (private communication) also assayed the diets 6 months later, and obtained $\mathrm{NPU}_{\text {op }}$ values of $22(\mathrm{~B}), 20(\mathrm{C}), 43(\mathrm{D}), 36(\mathrm{E}), 50(\mathrm{G})$ and $39(\mathrm{H})$. 


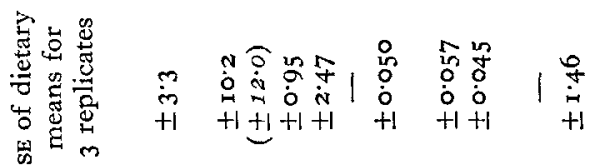

.

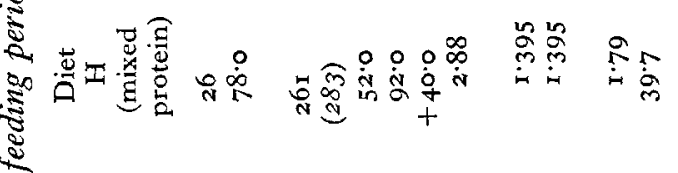

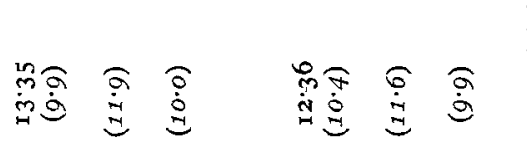

兽 $+\frac{1}{+}$

$\mp$

కุ

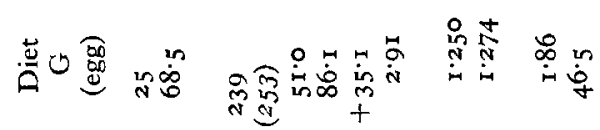

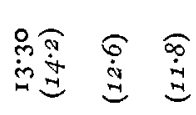

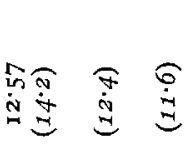

$\frac{\sqrt{2}}{2}$

2

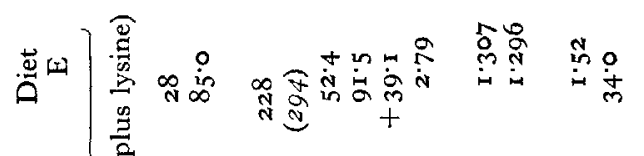

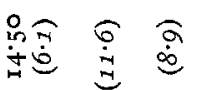

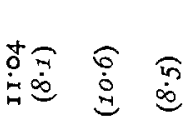

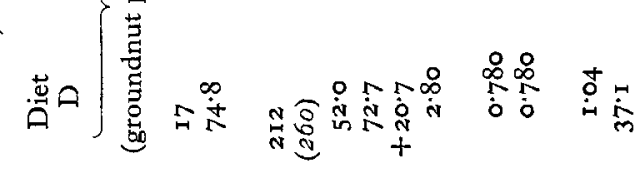

$\begin{array}{lll}\mathbb{4} & \widehat{O} & \mathbb{0} \\ \dot{0} \infty & \dot{0}\end{array}$

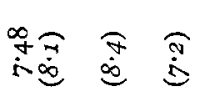

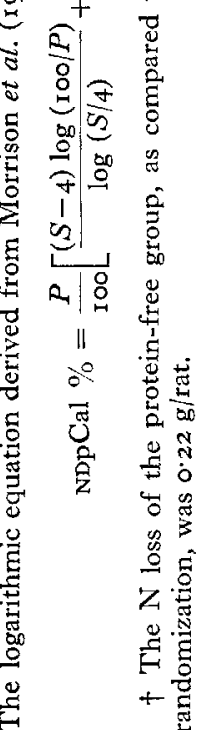

2

5

is

(ั)

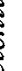

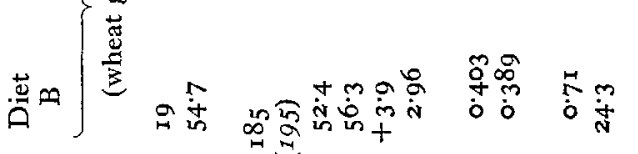

ำ

$i-\dot{b} \infty$

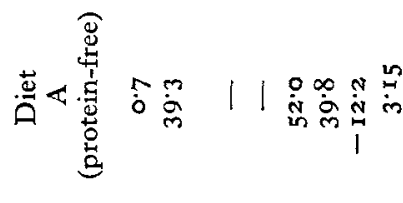

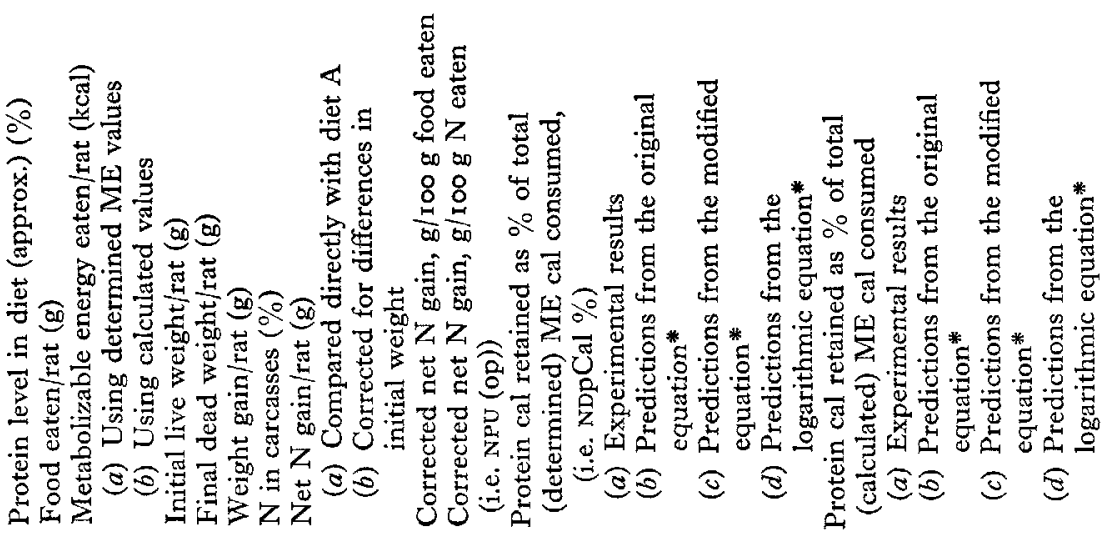




\section{DISCUSSION}

\section{Prediction equations}

Chemical scores. The prediction equations of Miller \& Payne (1961, I963, I964a) require each protein under consideration to have a 'score' assigned to it. The principle of calculating scores for proteins was first suggested by Block \& Mitchell (1946-7), who expressed the level of each essential amino acid in a test protein as a percentage of the level of that amino acid in egg protein; they took the lowest percentage as that 'limiting' the value of the protein and called it the 'chemical score' of the material.

For groundnut flour they calculated methionine to be limiting with $\mathrm{I} \cdot 2 \mathrm{~g} / \mathrm{I} 6 \mathrm{~g} \mathrm{~N}$ in the material, compared with $4.1 \mathrm{~g} / \mathrm{1} 6 \mathrm{~g} \mathrm{~N}$ in egg, giving a chemical score of 29 . With the modified analysis for egg of $3.2 \mathrm{~g}$ methionine $/ 16 \mathrm{~g} \mathrm{~N}$ recommended later (Rutgers University: Bureau of Biological Research, 1950), threonine becomes apparently limiting with a score of $3 \mathrm{I}$ (Bender, I954).

FAO (I957) replaced the egg standard by a hypothetical 'reference protein' with a provisional amino acid pattern corresponding to human needs. Methionine was again the limiting amino acid, with a tabulated analytical value of $0.9 \mathrm{~g} / \mathrm{1} 6 \mathrm{~g} \mathrm{~N}$ against $2.3 \mathrm{~g} /$ $16 \mathrm{~g} \mathrm{~N}$ in the reference protein, giving a score of 39 . However, this value is not taken and the next limiting factor, 'total sulphur-containing amino acids' is used, which gives a score of 56 against the $4.3 \mathrm{~g} / 16 \mathrm{~g} \mathrm{~N}$ in the reference protein. In a later publication $\left(\mathrm{FAO}, 19^{65}\right)$ all the scores are rounded to the nearest ' 10 ', so that the score for groundnut flour now appears as 60 . Bender (1961), using a target mixture containing $4.7 \mathrm{~g}$ sulphur-containing amino acids $/ \mathrm{r} 6 \mathrm{~g} \mathrm{~N}$, calculated scores ranging from 43 to 60 according to the analyses reported for individual samples of groundnut flour.

It is seen from this survey for a single material that there is no one value which can be regarded as the score for a particular type of material. If, as may well be needed for a processed material like groundnut flour, one has to consider the nutritional availability of the amino acids present in a particular sample, the position is complicated even further.

Application of prediction equations. Miller \& Payne (1961), in applying their prediction equation NDpCal $\%=b\left(P-0.019 P^{2}\right)$ for performance at maintenance levels of protein and above, used the score $S$, given by FAO (1957) as the best estimate of NPU at maintenance itself, which corresponds in their experience to an $\mathrm{NDpCal} \%$ of 4 . From this it follows that the best estimate of $b$ in the equation is $S /(100-760 / S)$, and this has been used for the predictions shown in Table 4 .

Miller \& Payne (1963) revised their original equation to $\mathrm{NDpCal} \%=(P S / \mathrm{roo})$ $\times(\mathrm{I}-0.019 P)$, and applied it both above and below nitrogen maintenance. However, in that paper the term $S$ is not related to any particular set of tables. In the examples given, by way of illustration, of egg and wheat gluten the values now used for $S$ are such that the response curves above maintenance, for NDpCal \% plotted against $P$, are almost identical with those shown earlier (Miller \& Payne, I96r). If FAO (I957) scores had been used then the predictions would have been lower.

The modified equation (P. R. Payne, private communication), of the hyperbolic 
type (Payne, I966), shown in the footnote to Table 4 , has constants chosen for use with FAO (1957) scores.

Morrison, Sabry, Gridgeman \& Campbell (I963) suggested that the experimental data then available for NPU at different levels of $P$ fitted a linear regression more closely if $P$ was plotted on a logarithmic scale rather than a linear one. Their "equation 5 ', if one multiplies both sides by $P$, becomes:

$$
\text { NDpCal } \left.\% \text { (i.e. } \frac{P}{100} \times \mathrm{NPU}\right)=\frac{P}{100}\left[\frac{(S-4) \log (100 / P)}{\log \frac{1}{4} S}+4\right] \text {. }
$$

$S$ again stands for score as published by FAO (1957).

Predicted and experimental values. The general shape of response curves plotted from the three equations for scores of 56 and 40 respectively is shown in Fig. I. Payne's modification of the original equation entirely alters the shape of the expected response at higher levels of protein. The logarithmic equation (Morrison et al. I963) gives an intermediate response curve.

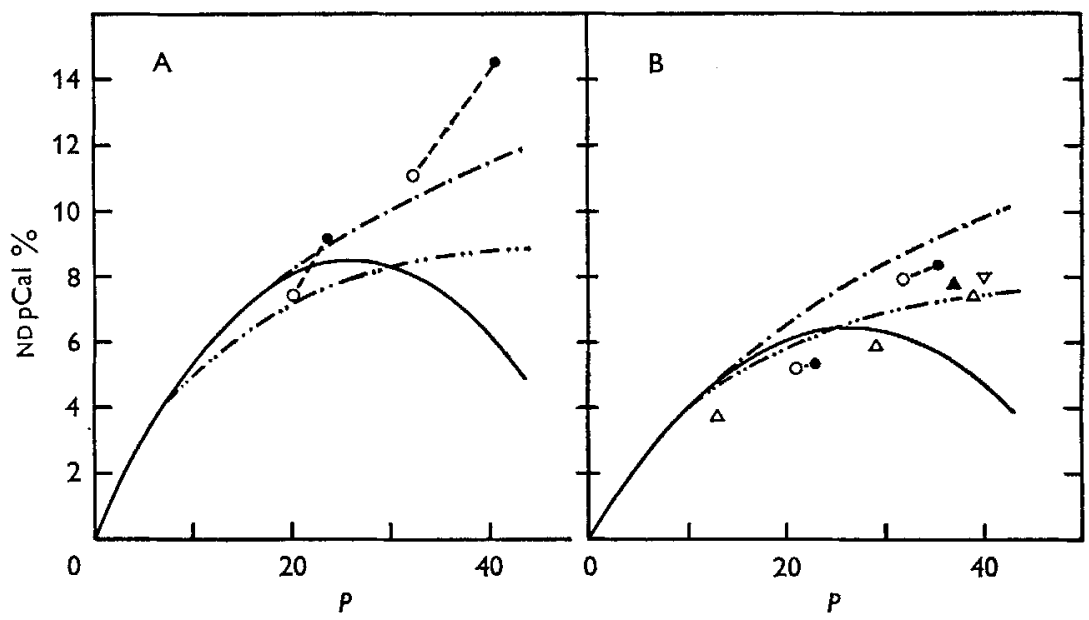

Fig. I. NDpCal \%, the retention of nitrogen (expressed as protein calories per roo calories eaten) by rats receiving (A) groundnut flour plus lysine or (B) wheat gluten as their sole protein source in the diet at different levels, $P(\%$ of $\mathrm{ME}$ from protein). $O$, our own results based on 'calculated' ME values; - , our own results based on 'determined' ME values (- - - , joining the two plots for the same diet); $\triangle$, results of Barnes, Bates \& Maack (1946);

$\boldsymbol{A}, \nabla$, results for $\boldsymbol{P}$ value of 40 (Miller \& Payne, 1961; Morrison et al. 1963, respectively). - , plot of the prediction equation

$$
\text { NDpCal } \%=\frac{S \times P(\text { I-0.019P })}{\text { I00-760/S }} \quad \text { (Miller \& Payne, I96r) }
$$

- - , plot of modified equation,

$$
\text { NDpCal } \%=\frac{P S \times 1.25}{100+0.064 P S} \quad \text { (P. R. Payne private }
$$

communication); - -.-, plot of logarithmic equation,

$$
\mathrm{NDpCal} \%=\frac{P}{I 00}\left[\frac{(S-4) \cdot \log (\mathrm{xoO} / P)}{\log \frac{1}{4} S}+4\right] \quad \text { (derived from }
$$

Morrison et al. 1963). In each equation $S$ is taken as 56 for groundnut plus lysine and $4 \circ$ for wheat gluten. 
Where our own results are to be plotted on the figure depends on whether the metabolizable energy values to be taken for the diets are those actually determined or those calculated on the assumption that $95 \%$ of the gross energy is digestible. Only the former seem likely to have any real significance for protein metabolism, but results calculated on both bases are plotted on the figure. It is seen that the differences were large only with groundnut flour plus lysine.

For wheat gluten the difference between actual and calculated ME is only small. Another series of published values is also plotted, together with the values for $\boldsymbol{P}$ levels of approximately 40 in each of two series where the results were only shown graphically. From inspection of the graphs it appears that there is reasonably good agreement between the different results.

The original Miller-Payne equation gives values differing markedly from the actual pattern of response, whatever scores are taken for the two test materials. With all the diets, the higher level of protein gave the higher $\mathrm{N}$ retention per kcal ME fed (whether of 'determined' or 'calculated' ME), whereas the equation predicted a falling off in response at levels of $P$ higher than 26. However, the pattern of the determined responses was closer to that of the modified equation; by adjusting the scores chosen for the two samples closer fits could be obtained.

The predicted values for all the diets are set out in Table 4. For the 'mixed protein' of diet $\mathrm{H}$ a score was calculated from the values for amino acid composition given by FAO (1957), applying the composition given there for 'fish' to herring meal, and taking values for gelatin and yeast given by De Man \& Zwiep (I955). It was calculated that the total sulphur-containing amino acids would be limiting with a score of 73 . Diet $\mathrm{H}$ gave as good a performance as diet $\mathrm{G}$ (egg protein), a result which was again clearly different from the prediction with the original equation. Even with the two modified equations, the predicted values were less for $\operatorname{diet} H$ than for $\operatorname{diet} G$, but not by an amount that could be detected with the standard errors of the experimental results.

\section{Comparisons of experimental results}

The general agreement between workers as to the responses obtained with high levels of wheat gluten is illustrated in Fig. I. With groundnut meal, only Forbes, Vaughan \& Yohe (I958) appear to have reported the result of feeding high levels to rats. For their diet of highest protein content, containing $24.5 \%$ protein, the biological value was 44 . If the true digestibility of the protein is taken as $90 \%$ and the $P$ value of the diet as 28 , the result is equivalent to a NDpCal \% of approximately $\mathrm{I}$. This is in agreement with our own findings.

Our conclusion is that it is possible for rats to show high $\mathrm{N}$ retentions when receiving poor proteins at high levels. This has also been the conclusion of Hegsted (1964) and Hegsted \& Chang (1965), and it has been agreed that the original prediction equation may not apply at high protein levels (Miller \& Payne, 1964 $b$; Payne, I966).

Payne's modified equation (P. R. Payne, private communication) is also in harmony with the conclusion of Hegsted \& Chang ( $196_{5}$ ) that the 'replacement equivalents' for different proteins are constant. For example, if twice as much of protein $B$ as of protein $\mathrm{A}$ is required to attain a NDpCal \% of 4 , then twice as much will also be re- 
quired to attain any other level of NDpCal \%. The modification represents a reversal of the view implicit in the earlier equations (Miller \& Payne, I961, 1963) that high protein levels greatly reduced the growth obtainable with a given dietary level of the limiting amino acid.

On the other hand, Payne's equation is not in harmony with Hegsted \& Chang's ( I $^{6} 5$ ) conclusion that responses to supplementary protein remain essentially linear, up to the point of maximum growth rate; it predicts instead a curvilinear response from quite low levels with no definite 'break' corresponding to the achievement of optimum growth. The present experiments were not designed to investigate this difference.

Whether or not any predictive formula, based on chemical score and protein concentration alone, will be completely successful remains to be seen. There is certainly the possibility that the response at high levels will be influenced by the proportions of specific amino acids other than the one calculated to be most limiting, in particular materials.

We are grateful to Mr P. R. Payne (Human Nutrition Research Unit, Medical Research Council, London) and Dr J. Davidson (Rowett Research Institute, Aberdeen) for carrying out some check analyses, to Mr D. S. Miller (Queen Elizabeth College, London) for arranging the supply of dried egg and wheat gluten; also to Mr Payne and Mr Miller for discussing the work with us at all stages. Miss Janice Nixon of the Agricultural Research Council's Statistics Group, Cambridge, helped with the analysis of our results on the Titan computer. One of us (K.A.) was in receipt of a Broodbank Fellowship from the University of Cambridge.

\section{REFERENCES}

Anantharaman, K. \& Carpenter, K. J. (1967). Proc. Nutr. Soc. 26, xi.

Anantharaman, K., Carpenter, K. J. \& Nesheim, M. C. (1968). Br. F. Nutr. 22, I99.

Association of Official Agricultural Chemists (1965). Official Methods of Analysis, roth ed. Washington, D.C. : Association of Official Agricultural Chemists.

Barnes, R. H., Bates, M. J. \& Maack, J. E. (1946). F. Nutr. 32, 535.

Bender, A. E. (1954). F. Sci, Fd Agric. 5, 305.

Bender, A. E. (1961). Publs nain. Res. Coun. Wash. no. 843, p. 407.

Black, A. E. \& Cuthbertson, W. F. J. (1963). Proc. Nutr. Soc. 22, xxi.

Block, R. J. \& Mitchell, H. H. (1946-7). Nutr. Abstr. Rev. 16, 249.

Carew, L. B., Hopkins, D. T. \& Nesheim, M. C. (1964). f. Nutr. 83, 300.

Carpenter, K. J. (1960). Biochem. F. 77, 604.

Carpenter, K. J. \& Anantharaman, K. (1967). Proc. Nutr. Soc. 26, xi.

Carpenter, K. J., March, B. E., Milner, C. K. \& Campbell, R. C. (1963). Br. F. Nutr. 17, 309.

Carpenter, K. J. \& De Muelenaere, H. J. H. (1965), Proc. Nutr. Soc. 24, 202.

Chapman, D. G., Castillo, R. \& Campbell, J. A. (I959). Can. F. Biochem. Physiol. 37, 678.

Coomes, T. J., Crowther, P. C., Francis, B. J. \& Stevens, L. (1965). Analyst, Lond. 90, 492.

Czarnocki, J., Sibbald, I. R. \& Evans, E. V. (1960). Can. F. Anim. Sci. 4I, I67.

De Man, T. J. \& Zwiep, N. (1955). Voeding 16, 147.

Dreyer, J. J. (1964). Proc. Soc. Adv. Anim. Nutr. S. Africa r, I9.

FAO (1957). F.A.O. nutr. Stud. no. 16.

FAO (1965). F.A.O. Nutr. Mtg Rep. Ser. no. 37 .

Forbes, E. B., Black, A., Thacker, E. J. \& Swift, R. W. (1940). F. Nutr. 20, 47.

Forbes, R. M., Vaughan, L. \& Yohe, M. (I 958). F. Nutr. 64, 291.

Ford, J. E. (1962). Br. F. Nutr. 16, 409.

Fox, M. R. S. \& Briggs, G. M. (1960). F. Nutr. 72, 243, 
Hegsted, D. M. (1964). In Mammalian Protein Metabolism. Vol. 2, chap. r4. [H. N. Munro \& J. B. Allison, editors.] New York and London: Academic Press Inc.

Hegsted, D. M. \& Chang, Y-O. (1965). F. Nutr. 87, 19.

Lee, W. V. (1965). Analyst, Lond. 90, 305 .

Ma, T. S. \& Zuazaga, G. (1942). Ind. Engng Chem. analyt Edn 14, 280.

McOsker, D. E. (1 962). F. Nutr. 76, 453.

Miller, D. S. (1963). In Publs natn. Res. Coun., Wash. no. I 100, appendix C, p. 34.

Miller, D. S. \& Bender, A. E. (1955). Br. F. Nutr. 9, 382.

Miller, D. S. \& Payne, P. R. (1959). Br. F. Nutr. 13, 50 I.

Miller, D. S. \& Payne, P. R. (I961). Br. F. Nutr. I5, I I.

Miller, D. S. \& Payne, P. R. (1963). F. theor. Biol. 5, 1398.

Miller, D. S. \& Payne, P. R. (I964a). Nature, Lond. 204, 480.

Miller, D. S. \& Payne, P. R. (I $964 b$ ). Proc. Nutr. Soc. 23, i I.

Miller, E. L., Carpenter, K. J., Morgan, C. B. \& Boyne, A. W. (1965). Br. F. Nutr. r9, 249.

Morrison, A. B., Sabry, Z. I., Gridgeman, N. T. \& Campbell, J. A. (x963). Can. F. Biochem. Physiol. $4 x, 275$

Payne, P. R. (1966). Proc. int. Congr. Nutr. vil. Hamburg. Vol. 4, p. 357.

Rutgers University: Bureau of Biological Research (1950). Cooperative Determinations of the Amino Acid Content, and of the Nutritive Value of Six Selected Protein Food Sources. New Brunswick, N.J.; Rutgers University Press. 